\title{
The gut in HIV infection
}

\author{
M. ZEIZ*, R. ULRICH and E.-O. RIECKEN
}

\section{INTRODUCTION}

The acquired immunodeficiency syndrome (AIDS) is caused by a human retrovirus which was originally designated by a variety of names including HTLV III (human T lymphotropic virus III) and LAV (lymphadenopathy virus $^{1,2}$, and which is now called human immunodeficiency virus (HIV). HIV is a member of the lentivirus subfamily. A second human lentivirus, HIV-2, has been isolated from patients with AIDS, especially in Africa, which is a novel member of the human lentivirus family and not an envelope variant of original isolates of $\mathrm{HIV}^{\mathbf{3 , 4}}$. The original isolates are now designated as HIV-1. Since the first description of AIDS cases in 1981 this disease has spread as an epidemic, and is now a major health problem all over the world. The number of patients with AIDS registered by the WHO in the middle of 1990 is more than 250000 worldwide ${ }^{5}$. The estimated number of individuals infected with HIV is 6-8 million by 1990 .

HIV has the ability to cause progressive deterioration of the host's immune function leading to opportunistic infections and neoplasms, the hallmarks of AIDS. A high proportion of patients infected with HIV suffers from gastrointestinal symptoms ${ }^{6-8}$. Although infections by opportunistic and other enteric pathogens are a major cause of these disturbances, it is important to note that even when thorough and repeated investigations are used a significant fraction of patients remains in whom neither opportunistic causes nor other intestinal pathogens can be found. This clinical finding has given rise to the hypothesis that HIV itself might cause intestinal dysfunction ${ }^{9,10}$. Such an 'HIV-induced' enteropathy might either be caused by direct damage of intestinal epithelial cells by HIV, or mucosal integrity could be disturbed by changes in the mucosal immune system, since a close relationship between

* Supported by a grant from the Bundesminister für Forschung und Technologie (FKZ II-048-88) 
the local immune system and enterocyte growth and function has been shown in several studies ${ }^{11,12}$ (see Chapter 8 in this volume).

In this chapter data on HIV infection of the intestinal mucosa, changes in the intestinal immune system, as well as structural and functional changes of the small intestinal mucosa in HIV infection will be discussed. Based on these data a hypothesis will be put forward that HIV itself is an intestinal pathogen causing a characteristic pattern of small intestinal damage.

\section{GASTROINTESTINAL MANIFESTATIONS IN HIV INFECTION}

Gastrointestinal symptoms such as diarrhoea, weight loss, abdominal pain, vomiting, and dysphagia are among the most common and devastating problems in HIV-infected patients. These symptoms can in part be attributed to a wide variety of opportunistic and other enteric pathogens (Table 12.1) as well as secondary malignancies like Kaposi's sarcoma and malignant lymphomas ${ }^{8,13-16}$. However, even repeated investigations of multiple stool samples and intestinal biopsies including electron microscopy and immunohistology fail to identify a known cause of the gastrointestinal symptoms in a significant proportion of the patients (Fig. 12.1). The percentage of patients with diarrhoea in whom no intestinal pathogen is identified varies in different

Table 12.1 Frequency of opportunistic and non-opportunistic gastro-intestinal pathogens in patients with HIV infection and gastrointestinal symptoms

\begin{tabular}{ll}
\hline Agents & Rates of detection $(\%)$ \\
\hline Adenovirus & $3-6$ \\
B. hominis & $7-14$ \\
C. difficile & $1-6$ \\
C. perfringens & 1 \\
Campylobacter sp. & $2-10$ \\
Chlamydia sp. & $1-3$ \\
Coronavirus & 1 \\
Cryptosporidium & $5-59$ \\
Cytomegalovirus & $7-45$ \\
E. histolytica & $3-25$ \\
G. lamblia & $2-15$ \\
Herpes simplex virus & $4-29$ \\
I. belli & $1-19$ \\
M. avium Complex & $5-25$ \\
M. tuberculosis & $1-3$ \\
Salmonella sp. & $1-15$ \\
Shigella sp. & $1-10$ \\
Spirochetes & $1-9$ \\
Yersinia sp & 1 \\
None & $15-56$ \\
\hline
\end{tabular}

Values were taken from references $10,15-20,106$, and own unpublished results. 


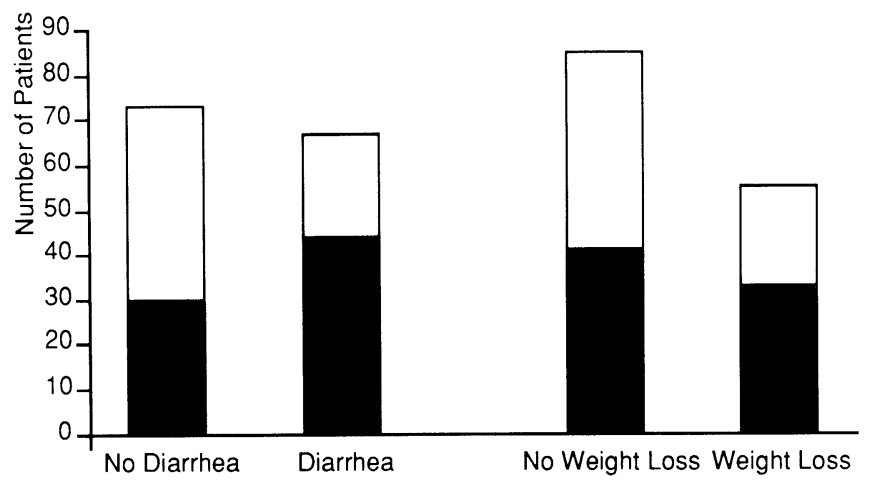

Figure 12.1 Frequency of gastrointestinal pathogens in 159 AIDS patients with and without diarrhoea or weight loss. At least three different stool samples and gastrointestinal biopsies were investigated. Diarrhoea is significantly associated with the presence of an intestinal pathogen $(p<0.05)$. However, intestinal pathogens are also present in patients without diarrhoea, and a considerable fraction of patients with diarrhoea remains, in whom no pathogen can be found. There is no significant association between weight loss and the presence of an intestinal pathogen (own unpublished results)

studies between $15 \%$ and $50 \% \%^{10,15-19}$. Furthermore, when analysing the presence of intestinal pathogens in stool or biopsy in relation to the presence or absence of gastrointestinal symptoms, the causative relevance of several agents detected remains questionable ${ }^{20}$ (own results; submitted for publication, see also Fig. 12.1).

Evidence that small intestinal dysfunction with malabsorption may occur in HIV-infected patients and contribute to diarrhoea and weight loss is provided in several studies $9,10,13,21$. Laboratory parameters indicative of malabsorption, such as serum albumin, calcium, zinc, folic acid, and vitamin $B_{12}$, are reduced in a significant percentage of $\mathrm{HIV}$-infected patients. Reduced serum concentrations are found even at early disease stages ${ }^{10}$. Direct tests of absorptive function were also performed in HIV-infected patients with gastrointestinal symptoms: significant fat malabsorption was found in $29-80 \%$, xylose malaborsption in $54-100 \%$, and vitamin $\mathrm{B}_{12}$ malaborsption in $75 \%$ of AIDS patients; however, the number of patients was low in these studies $9,10,13,21-24$. Lactase deficiency as measured by $\mathrm{H}_{2}$-exhalation after oral lactose ingestion was found in about $50 \%$ of HIV-infected patients even at early stages of the disease ${ }^{10}$. Again, malabsorption is also recognized in the absence of an additional enteric pathogen in a considerable percentage of patients. A recent study suggests that patients with severe weight loss, high stool volumes, and severe malabsorption are more likely to harbour an additional intestinal pathogen than patients with less severe gastrointestinal symptoms, in whom even repeated investigations fail to recognize a pathogen ${ }^{23}$.

Thus, although a wide variety of intestinal pathogens is found in HIV-infected patients with gastrointestinal symptoms, a fraction of patients remains in whom neither secondary infections nor malignancies are found; in addition, the pathogenic relevance of some abnormalities detected is doubtful. 


\section{HIV INFECTION OF THE INTESTINAL MUCOSA}

\section{Target cells of HIV infection}

The severe cellular immunodeficiency caused by HIV results from virus infecting CD4-positive T lymphocytes. The molecular mechanism of this cellular tropism is a high-affinity binding of HIV to the CD4 molecule via the HIV envelope glycoprotein, gp120 25 (Fig. 12.2). It has been shown that the affinity of gp120 to CD4 is even higher than that of MHC Class II molecules, the natural ligand of $\mathrm{CD} 4{ }^{25}$. With HIV infection the CD4-positive $\mathrm{T}$ cell is either killed or impaired in function ${ }^{2,26}$.

Subpopulations of monocytes and macrophages also express the CD4 antigen although in low density, and it has been shown that these cells can be infected with $\mathrm{HIV}^{27-30}$. A second mechanism by which macrophages and monocytes may be infected with HIV is the binding of antibody-HIV complexes to $\mathrm{Fc}$ receptors or complement receptors on these cells and subsequent phagocytosis of these complexes ${ }^{31,32}$ (Fig. 12.2). In contrast to the CD4-positive T cell, HIV-infected macrophages and monocytes are relatively resistant to the cytopathic effect of $\mathrm{HIV}^{27,33}$; these cells may therefore serve as an important reservoir for the persistance of HIV in the host.

In addition, it has been shown that follicular dendritic cells are also infected with HIV in vivo ${ }^{34-36}$. HIV-infected follicular dendritic cells were observed

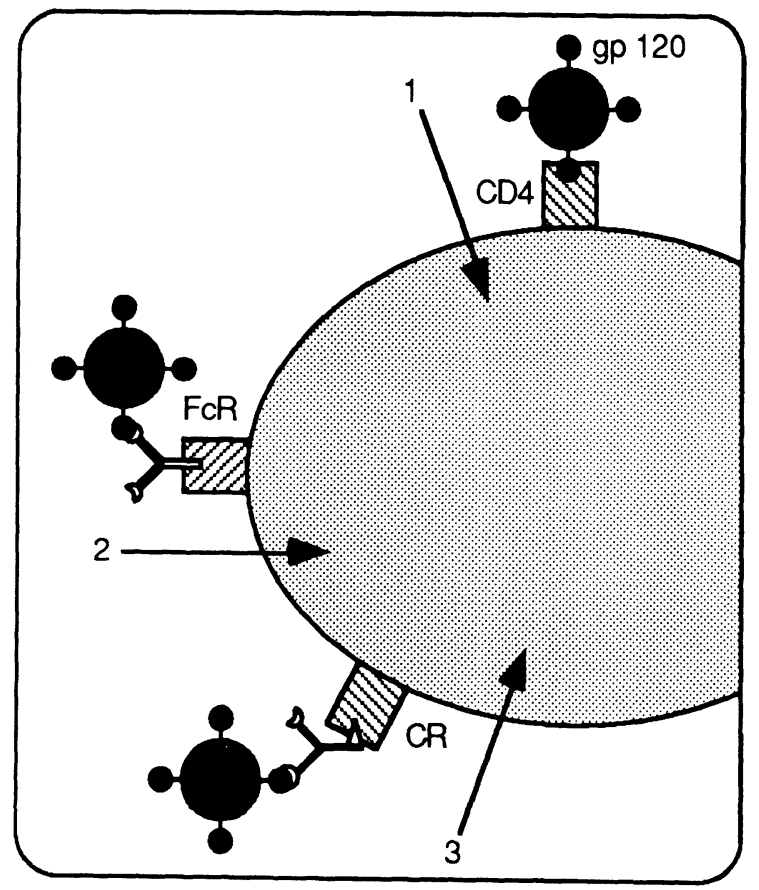

Figure 12.2 Possible mechanisms of cellular HIV infection: (1) HIV envelope antigen gp120 binds with high affinity to cell surface CD4 molecules followed by virus entry. (2) HIV-antibody complexes bind to $\mathrm{Fc}$ receptors on the cell surface followed by internalization of the complex. (3) HIV-antibody complexes bind to complement receptors on the cell surface 
both in peripheral lymph nodes and in intestinal mucosal lymphoid follicles ${ }^{37,38}$. The mechanism by which these cells are infected is not completely understood, as they lack the CD4 molecule and express only the low affinity Fc receptor for $\mathrm{IgE}^{35}$. Since follicular dendritic cells form an extensive network of cellular processes in the centre of lymph follicles, CD4-positive $T$ cells come into close contact with these cells and may become infected by direct cell-to-cell contact.

\section{Presence of HIV-infected cells in the mucosa}

Approximately $70 \%$ of T cells within the mucosa are targets for HIV because they bear the CD4 molecule on their surface (see below). Macrophages in the mucosa and follicular dendritic cells in mucosal lymphoid follicles may also be infected and constitute important reservoirs for HIV. Both immunohistology and in situ hybridization have been used to identify HIV-infected cells in the intestinal mucosa which were found in $30-50 \%$ of the investigated patients ${ }^{10,37,39,40}$ (Table 12.2). HIV-infected mononuclear cells in the lamina propria were found in all studies and morphologically assessed as lymphocytes or macrophages; however, the definite identification of the cell type infected with HIV was not possible in these studies. In one study, binding of HIV-specific DNA probes predominantly to basal crypt cells was reported, and infected cells were identified as enterochromaffine cells, enterocytes, and goblet cells using an argentaffin stain and morphology ${ }^{39}$. However, in the remaining studies HIV-infected cells were either completely absent in the epithelial layer ${ }^{40}$ or very rarely observed, and assessed rather as intraepithelial lymphocytes ${ }^{10,37}$. These differences might therefore be due to technical reasons rather than reflect true biological differences. Thus while intestinal epithelial cells in vitro are infectable by HIV $^{41}$ even in the absence of detectable CD4 expression ${ }^{42}$, the relevance of this finding remains to be studied, since its demonstration in vivo is controversial; furthermore, no cytopathic alterations were documented in HIV-infected epithelial cell lines ${ }^{41}$.

Table 12.2 Summary of different studies on the presence of HIV-infected cells in the intestinal mucosa in patients with HIV infection

\begin{tabular}{|c|c|c|c|c|c|}
\hline & $\begin{array}{l}\text { Patients/ } \\
\text { stage }\end{array}$ & Method & $\begin{array}{l}\text { HIV- } \\
\text { detection }\end{array}$ & Infected cells & Localization \\
\hline $\begin{array}{l}\text { Nelson } \\
\text { et } \text { al. }^{39}\end{array}$ & $10 / \mathrm{IV}$ & $\begin{array}{l}\text { DNA } \\
\text { Hybridization }\end{array}$ & $5 / 10$ & $\begin{array}{l}\text { Enterochromaffine } \\
\text { and goblet cells, } \\
\text { enterocytes, mono- } \\
\text { nuclear cells }\end{array}$ & $\begin{array}{l}\text { Cryptbase, lamina } \\
\text { propria }\end{array}$ \\
\hline $\begin{array}{l}\text { Ullrich } \\
\text { et al. }{ }^{10}\end{array}$ & $\begin{array}{l}11 / \mathrm{II} \text { or III, } \\
40 / \mathrm{IV}\end{array}$ & $\begin{array}{l}\text { Immuno- } \\
\text { histology }\end{array}$ & $20 / 51$ & Mononuclear cells & $\begin{array}{l}\text { Lamina propria, } \\
\text { two intraepithelial }\end{array}$ \\
\hline $\begin{array}{l}\text { Fox } \\
\text { et al. }{ }^{40}\end{array}$ & $25 / \mathrm{IV}$ & $\begin{array}{l}\text { RNA } \\
\text { Hybridization }\end{array}$ & $7 / 25$ & Mononuclear cells & Lamina propria \\
\hline $\begin{array}{l}\text { Jarry } \\
\text { et } a l^{37}\end{array}$ & $127 / \mathrm{IV}$ & $\begin{array}{l}\text { Immuno- } \\
\text { histology }\end{array}$ & $38 / 127$ & $\begin{array}{l}\text { Mononuclear cells, } \\
\text { (one dendritic, } \\
\text { one epithelial cell) }\end{array}$ & $\begin{array}{l}\text { Lamina propria, } \\
\text { two intraepithelial }\end{array}$ \\
\hline
\end{tabular}


In conclusion, the studies available at present document HIV infection of mononuclear cells in the intestinal lamina propria, whereas the significance of HIV infection of epithelial cells is questionable.

\section{IMMUNOPATHOGENIC MECHANISMS OF HIV INFECTION}

\section{Consequences of HIV infection for $T$ cell function}

HIV infection causes depletion of CD4-positive T cells. The exact mechanism for the cytotoxic effect of HIV is still not completely understood (Table 12.3). Several mechanisms have been discussed: intensive virus budding may be responsible for the formation of microholes in the cell membrane ${ }^{43}$, insertion of HIV envelope glycoproteins in the T cell membrane may cause changes in membrane permeability to ions $\mathbf{s}^{44}$, and there is also evidence that binding of gp120 to intracellular CD4 induces cell death ${ }^{45}$. Accumulation of unintegrated viral DNA in the cytoplasm is also highly toxic for the cell ${ }^{46}$. The well-known phenomenon of syncytia formation after in vitro infection of CD4 T cells with HIV may be caused by binding of gp120 on the cell surface of infected cells to CD4 of neighbouring uninfected T cells ${ }^{47,48}$. Autoimmune phenomena to CD4 T cells bearing gp120 on their surface have also been described in HIV-infected patients: both antibody-dependent cytotoxicity and cellular cytotoxic mechanisms may be of relevance ${ }^{4-51}$.

The selective killing of the CD4-positive $T$ cell subset, which plays a central role in the immune response, will compromise the function of a variety of other cell types resulting in multiple immunological deficits of the organism ${ }^{26,52}$. The different subsets of the CD4-positive lymphocyte population are intimately involved in B cell function, differentiation of cytolytic $\mathrm{T}$ cells, suppressor $\mathrm{T}$ cell function, natural killer cell activity and certain macrophage/monocyte functions.

In addition to the depletion of CD4 $\mathrm{T}$ cells, abnormalities in CD4 $\mathrm{T}$ cell function have been observed at all stages of HIV infection (Table 12.3). Helper

Table 12.3 Consequences of HIV infection on $\mathrm{T}$ cell function

Cytotoxic effects of HIV

Formation of microholes in the cell membrane

Changes in cell membrane permeability

Accumulation of unintegrated viral DNA in the cytoplasm

Binding of HIV envelope proteins to intracellular CD4 molecules

Syncytia formation by binding of HIV antigen gp120 to surface CD4 molecules

Autoimmune processes to CD4-positive T cells bearing gp120 on the surface

Non-cytotoxic effects of $\mathrm{HIV}$

Disturbed helper function of CD4 T cells for B cell differentiation

Decreased proliferation of $T$ cells to soluble and viral antigens

Defective IL- 2 and interferon- $\gamma$ production by $\mathrm{T}$ cells

Low anti-CD3 reactivity of $T$ cells

Impairment of signal transduction

Downregulation of the genes for CD4, CD3, CD2, and CD25

Decrease in CD29 expression ('memory' $\mathrm{T}$ cells) 


\section{THE GUT IN HIV INFECTION}

activity for B cell differentiation is disturbed ${ }^{53}, \mathrm{~T}$ cell proliferative responses to soluble and viral antigens are decreased even at early stages of HIV infection ${ }^{54-57}$, antigen-induced interferon- $\gamma$ production ${ }^{58}$ and IL-2 production ${ }^{59}$ by $\mathrm{T}$ cells is low. $\mathrm{T}$ cell proliferation to anti-CD3 antibodies is decreased, and low anti-CD3 reactivity, independent of the number of CD4-positive $\mathrm{T}$ cells, seems to be of predictive value for progression to $\operatorname{AIDS}^{60}$. HIV infection has been reported to down-regulate cellular genes or inhibit synthesis of proteins critical for $\mathrm{T}$ cell function such as $\mathrm{CD} 4^{45,61}, \mathrm{CD} 3, \mathrm{CD} 2$, and CD25 $\left(\alpha\right.$-chain of the IL-2 receptor) ${ }^{62,63}$. There is also evidence for an early loss of CD29-positive memory T cells in HIV infection ${ }^{64,65}$.

Viral antigens themselves may have stimulatory effects on T cells: HIV envelope peptides induce proliferation of $T$ cells, and native gp120 induces increased IL-2 receptor expression in T cells ${ }^{66-68}$. In contrast, the response of CD4-positive $T$ cells activated by mitogen or antigen is suppressed by HIV and HIV antigen preparations, notably gp $120^{66}$.

Thus, besides its direct cytopathic effect, HIV alters $\mathrm{T}$ cell function in several ways, and these functional abnormalities probably contribute substantially to the pathogenesis of the progressive immune dysfunction in HIV infection. Disturbed function of CD4-positive T cells may also be of special importance for immunoregulation at mucosal surfaces, since activated CD4-positive $\mathrm{T}$ cells predominate in this compartment of the immune system (see below).

\section{Role of $\mathbf{T}$ cell activation in HIV replication}

After entry of HIV into the target cell viral RNA is transcribed into DNA by viral reverse transcriptase. HIV-specific DNA then is partially integrated into the host genome and partially remains unintegrated in the cytoplasm. Once the HIV proviral DNA is integrated in the host's chromosomal DNA, viral replication may enter a latent phase, depending on the state of activation of the infected cell ${ }^{69,70}$. In resting T cells no or very low-level virus expression is observed. This may be due to a regulatory protein, rpt-1, which is selectively expressed in resting CD4 T cells, and which down-regulates both the promoter region of the IL-2 receptor $\alpha$-chain gene and the expression of the HIV $\mathrm{LTR}^{71}$. Activation of infected lymphocytes is followed by transcription, protein synthesis, post-translational processing, assembly of viral RNA and protein and finally budding of the mature virions ${ }^{69}$. Recent studies indicate that factors specific to activated $T$ cells stimulate viral transcription by binding to regions on viral $\mathrm{DNA}^{72}$. It has been shown that the $\mathrm{T}$ cell activation factor, $\mathrm{NF} \kappa \mathrm{B}$, binds to a NF $\kappa \mathrm{B}$ binding site and activates in vitro transcription of the HIV promoter ${ }^{73}$.

$\mathrm{T}$ cell activation can be achieved in vitro by mitogenic, antigenic, or allogeneic stimuli; in vivo several concurrent infections may activate $T$ cells and thereby induce HIV replication. Coinfections with other viruses such as herpes simplex virus, cytomegalovirus, and Epstein-Barr virus have also been shown to upregulate HIV expression ${ }^{74-77}$. In addition, cytokines may be important in the efficient replication of HIV ${ }^{78,79}$. TNF- $\alpha$ is an especially 
potent stimulator of increased HIV expression of infected cell lines in vitro ${ }^{80-82}$. Thus, efficient replication of HIV is closely associated with activation of $T$ cells.

\section{Characteristics of lamina propria T cells as targets for HIV}

In recent years specific differences have been recognized between lamina propria $T$ cells and $T$ cells of other origin. Using immunohistochemical techniques on frozen tissue sections and flow cytometry on isolated lymphocytes it has been shown that intestinal lamina propria lymphocytes are predominantly of the helper/inducer phenotype (CD4-positive) ${ }^{83-86}$. In addition, lamina propria $T$ cells possess a low expression of the CD45RA antigen (recognized by monoclonal antibody $2 \mathrm{H} 4$ ) and a high expression of CD45R0 (recognized by UCHL-1 ${ }^{86,87}$. CD45RA-low, CD45R0-high T cells have been shown to represent memory $\mathrm{T}$ cells, i.e. $\mathrm{T}$ cells which have already been in contact with antigen ${ }^{\mathbf{8 8 , 8 9}}$. However, another marker of circulating memory $\mathrm{T}$ cells, CD29, is expressed only on about $50 \%$ of lamina propria $\mathrm{T}$ cells ${ }^{86,87}$. Lamina propria $\mathrm{T}$ cells therefore have an only partially overlapping phenotype with memory $\mathrm{T}$ cells. In addition, about $40 \%$ of $\mathrm{T}$ cells in the lamina propria express the T cell marker, HML-1, which is nearly exclusively found in the mucosa ${ }^{86,90}$. The specific phenotype of lamina propria $T$ cells corresponds functionally with a specific response to antigens: in an animal model of intestinal infection and inflammation (Chlamydia trachomatis proctitis of non-human primates) lamina propria $\mathrm{T}$ cells did not proliferate when stimulated in vitro with specific antigen, although $\mathrm{T}$ cells from mesenteric lymph nodes, the spleen, or the peripheral blood did proliferate under identical conditions. However, lamina propria $\mathrm{T}$ cells provided help for Ig synthesis after stimulation with the same antigen ${ }^{91}$. Thus lamina propria $\mathrm{T}$ cells resemble differentiated effector cells which carry out important immunoregulatory functions in the microenvironment of the mucosa in response to enteric pathogens.

Another important finding in the context of mucosal HIV infection is that lamina propria $\mathrm{T}$ cells are more activated than $\mathrm{T}$ cells in other compartments of the immune system. Using cytofluorometric analysis of intestinal lymphocytes it was shown that lamina propria lymphocytes have increased expression of CD25, the $\alpha$-chain of the IL-2 receptor, as compared to other T cells ${ }^{86,92}$. This result was confirmed at the molecular level: Northern blot analysis of lymphocytes isolated from different tissue sites revealed that only lamina propria lymphocytes contained clearly detectable mRNA for the IL-2 receptor without in vitro stimulation ${ }^{92}$. Other gene products associated with $\mathrm{T}$ cell activation were also studied: resting lamina propria $\mathrm{T}$ lymphocytes were similar to other T cells in that IL-2 was not detected in culture supernatants. However, after stimulation with mitogen, lamina propria lymphocytes synthesized significantly more IL-2 compared to the other populations ${ }^{92}$. The concept of an increased state of activation of lamina propria $\mathrm{T}$ cells is also supported by the finding that HML-1 is an activation antigen $^{86}$. In summary, these results clearly demonstrate that lamina propria 
$\mathrm{T}$ cells are more activated than $\mathrm{T}$ cells in other sites of the immune system; HIV infection of these cells might have specific consequences for $\mathrm{T}$ cell function in the intestinal mucosal immune system ${ }^{93}$ (Fig. 12.3).

\section{Mucosal T cells in HIV infection}

Disturbances of the mucosal immune system in HIV infection have been studied so far only by immunohistological and electron microscopical techniques. A reduction in the number of CD4-positive mononuclear cells, the known target cells of the AIDS virus, in the intestinal lamina propria has been described in several studies ${ }^{37,94-96}$. In our own investigations only a minor reduction in the number of CD4-positive cells has been found with an increase in the number of CD8-positive cells ${ }^{97,98}$. Thus, as in the circulation, the CD4/CD8 ratio is decreased in the lamina propria of the intestine in AIDS (Table 12.4). Impairment of $T$ cell function in the intestinal mucosa in HIV infection is indicated by the finding of a decreased number of CD25-positive cells (cells expressing the $\alpha$-chain of the IL-2 receptor) in the lamina propria ${ }^{97,98}$. One important finding in most of these phenotype studies is that the reduction in the number of CD4-positive cells in the intestinal lamina propria is considerably less pronounced compared to the

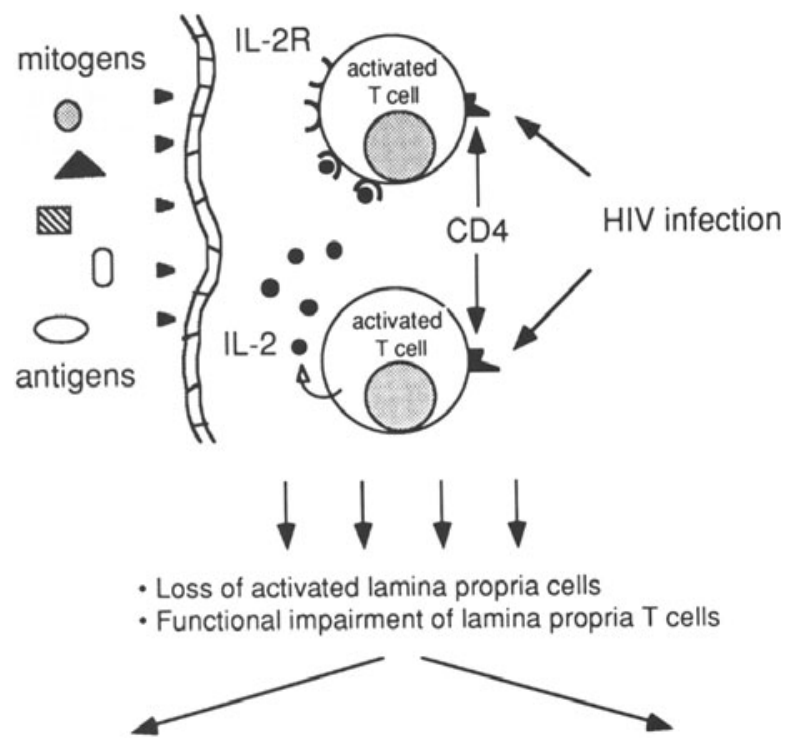

Secondary gastrointestinal infections

Impairment of intestinal epithelial Secondary malignancies

cell growth and differentiation

Figure 12.3 Infection by HIV of lamina propria CD4-positive $T$ cells may lead to functional impairment of these cells. Since CD4-positive $\mathrm{T}$ cells play a central role in immunoregulation at mucosal surfaces, the mucosal immune barrier subsequently may be disturbed leading to opportunistic and non-opportunistic infections. Loss of activated $\mathrm{T}$ cells in the mucosa may also influence the growth and differentiation of intestinal epithelial cells 
peripheral blood (Table 12.4). An explanation for this may be that the replication of HIV and its cytotoxic effect depend upon cellular activation and proliferation (see above). Intestinal lamina propria $T$ cells differ from circulating $T$ cells in both their state of activation and their inability to proliferate after stimulation with antigen. Therefore, HIV infection of intestinal CD4-positive cells may lead not to cell death, but rather to an impaired expression of surface markers essential for $T$ cell function such as the IL-2 receptor. The loss of activated cells in HIV infection with the relative preservation of CD4-positive $\mathrm{T}$ cells therefore indicates mainly a functional impairment of mucosal $\mathrm{T}$ cells which might also be a consequence of HIV infection (see above) (Fig. 12.3).

The number of intraepithelial lymphocytes in the large and small intestinal mucosa in different stages of HIV infection has been found to be normal in most studies ${ }^{99-101}$; a slight increase in the number might occur in the small intestine when compared to controls ${ }^{99}$. Using immunohistology a decrease in CD3-positive and CD8-positive intraepithelial lymphocytes per 500 epithelial cells was found ${ }^{37}$. An electron microscopical study has shown that intraepithelial lymphocytes in AIDS patients possess more granules and appear activated ${ }^{99}$. From the studies presently available no clear conclusions can be drawn regarding changes in intraepithelial lymphocyte phenotype and function in HIV infection.

Little information exists also on mucosal secretory immunity in HIV infection: a reduction of IgA-containing plasma cells in small intestinal and colonic biopsies from patients with AIDS has been reported, and an increase of IgM-containing plasma cells, while IgG-containing cells were found to be normal $^{102}$. In a recent study it was shown that salivary $\operatorname{IgA}_{1}$ levels were normal in AIDS patients, whereas $\operatorname{IgA}_{2}$ levels were markedly decreased ${ }^{103}$. Changes in immunoglobulin isotype expression in HIV infection might also be caused by abnormalities in mucosal $\mathrm{T}$ cells which regulate $\mathrm{B}$ cell isotype differentiation. Further studies clearly are needed to clarify the relevance of secretory mucosal immunity in AIDS.

Table 12.4 Lymphocyte subpopulations of the duodenal lamina propria in HIV infection

\begin{tabular}{|c|c|c|c|c|c|}
\hline & $\begin{array}{l}\text { Rodgers } \\
\text { et al. } .^{44}\end{array}$ & $\begin{array}{l}\text { Ellakany } \\
\text { et al. }{ }^{95}\end{array}$ & $\begin{array}{l}\text { Budhraja } \\
\text { et al. }{ }^{96}\end{array}$ & $\begin{array}{l}\text { Ullrich } \\
\text { et al. }{ }^{98}\end{array}$ & $\begin{array}{l}\text { Jarry } \\
\text { et al. }{ }^{37}\end{array}$ \\
\hline Number of patients & $5 \mathrm{C}, 12 \mathrm{HIV}$ & $10 \mathrm{C}, 6 \mathrm{HIV}$ & $7 \mathrm{C}, 14 \mathrm{HIV}$ & $20 \mathrm{C}, 51 \mathrm{HIV}$ & $10 \mathrm{C}, 33 \mathrm{HIV}$ \\
\hline $\mathrm{T}$ cells & $60 \%$ a & $80 \%$ a & $80 \%$ a & $120 \%$ & $115 \% \mathrm{a}$ \\
\hline CD4+ & $60 \% \mathrm{a}$ & $20 \% \mathrm{a}$ & $50 \% \mathrm{a}$ & $100 \% \mathrm{c}$ & $10 \% \mathrm{a}$ \\
\hline $\mathrm{CD} 8+$ & $130 \% \mathrm{a}$ & $200 \%$ & $180^{\circ} \%^{\mathrm{a}}$ & $160 \%$ c & $240 \% \%^{\mathrm{a}}$ \\
\hline \multicolumn{6}{|l|}{ CD4/CD8 } \\
\hline Controls & $1.8^{\mathrm{b}}$ & $2.3^{\mathrm{b}}$ & $0.8^{\mathrm{b}}$ & $1.9^{\mathrm{d}}$ & $1.7^{\mathrm{b}}$ \\
\hline HIV & $0.7^{\mathrm{b}}$ & $0.2^{\mathrm{b}}$ & $0.2^{\mathrm{b}}$ & $1.1^{\mathrm{d}}$ & $0.1^{\mathrm{b}}$ \\
\hline
\end{tabular}

$\mathrm{C}=$ Controls; $\mathrm{HIV}=\mathrm{HIV}$-infected patients

${ }^{\text {a }}$ Mean of HIV-infected patients/mean of controls

${ }^{b}$ Mean

${ }^{\mathrm{c}}$ Median of HIV-infected patients/median of controls

${ }^{\mathrm{d}}$ Median 


\section{SMALL INTESTINAL STRUCTURE AND FUNCTION IN HIV INFECTION}

The gut epithelium is functionally related to the mucosal immune system ${ }^{11,12}$ (discussed in detail elsewhere in this volume); e.g. hyperregenerative adaptation of the mucosa, i.e. villous atrophy with increased proliferation of crypt cells leading to crypt hyperplasia, is found in states of mucosal $\mathrm{T}$ cell activation both in vitro ${ }^{11}$ and in vivo ${ }^{104}$. Therefore, changes in mucosal architecture might reflect alterations in mucosal immunity. By three-dimensional morphometry of microdissected duodenal specimens partial villous atrophy was found in HIV-infected patients with gastrointestinal symptoms; however, the specific type of mucosal transformation was dependent on both the presence of secondary pathogens and mucosal HIV infection ${ }^{10}$. In patients with HIV-infected cells in the mucosa villous atrophy was accompanied by reduced crypt cell proliferation. If secondary infections were present, the number of mitotic figures per crypt were slightly increased but inappropriately to the villous atrophy resulting in impaired crypt hyperplasia. Thus HIV infection is associated with epithelial hypoproliferation ${ }^{10,105}$. In addition, the maturation of enterocytes is disturbed as indicated by decreased activities of brush-border enzymes ${ }^{10,97}$; e.g. lactase deficiency, the prevalence of which is about $10 \%$ in whites, was found in nearly $50 \%$ of white HIV-infected patients, and was significantly commoner in patients with mucosal HIV infection, secondary intestinal infections, or both as compared with controls. As discussed above, it is unlikely that these abnormalities in mucosal structure and function result from cytopathic HIV infection of enterocytes, since mucosal HIV infection was found restricted to mononuclear lamina propria cells in most studies. However, the findings fit into the concept of immune-mediated mucosal transformation (Fig. 12.4); crypt cell proliferation is induced by $\mathrm{T}$ cell activation; therefore the activated $\mathrm{T}$ cells present in the normal lamina propria might be involved in the maintenance of the normal mucosal architecture. The epithelial hypoproliferation seen in HIV-infected patients, which is most pronounced if mucosal HIV infection is found, thus indicates impaired activation of lamina propria $T$ cells. In fact, this has been demonstrated by reduced expression of CD25 in the lamina propria of HIV-infected patients ${ }^{98}$, and is in accordance with the suppressive effect of HIV on T cell activation induced by other stimuli as documented in vitro ${ }^{66}$. It is tempting to assume that enterocyte maturation is also influenced by the postulated as-yet-unidentified trophic factor(s) produced by activated lamina propria $T$ cells. Impairment or depletion of activated regulatory $T$ cells in the lamina propria by HIV might thus lead not only to a breakdown of the mucosal immune barrier resulting in a variety of opportunistic infections, but also to malabsorption due to mucosal atrophy or enterocyte dysfunction (see Fig. 12.3). The existence of such an HIV enteropathy is strongly supported by the presence of gastrointestinal symptoms and malabsorption in HIV-infected patients without detectable secondary abnormalities, and especially in early stages of the disease when HIV is virtually the only intestinal pathogen identifiable in a considerable proportion of patients. The intestinal abnormalities in HIV infection may thus represent a specific immunologically mediated form of an intestinal adaptation ${ }^{87,97,98}$. 


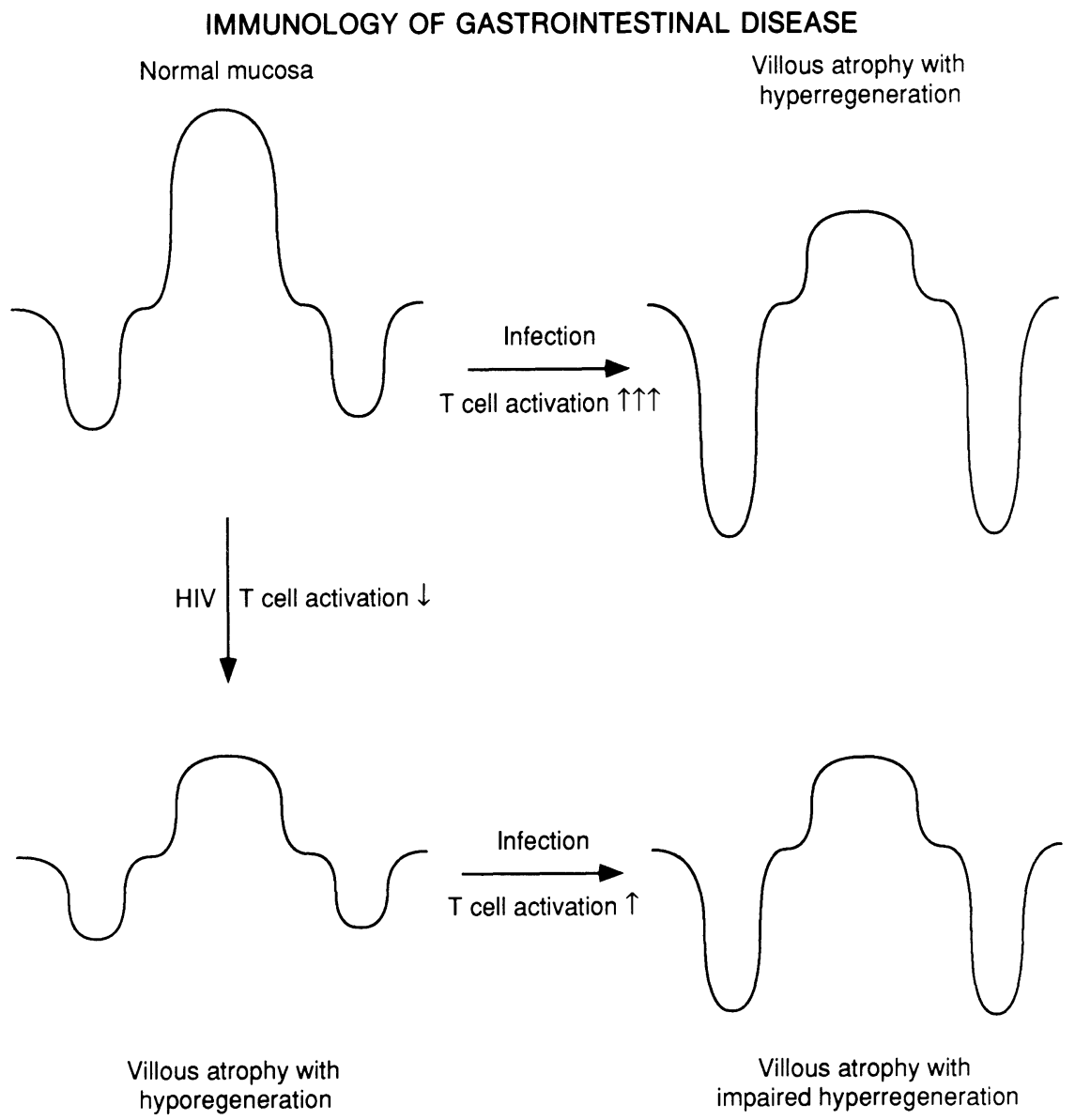

Figure 12.4 Impairment of mucosal T cell activation by HIV infection might cause enteropathy. Hyperregenerative villous atrophy is associated with, and can in vitro be induced by, $T$ cell activation. The normal architecture of the mucosa is maintained by the balance between villus cell slough and crypt cell proliferation, which probably is affected by the activated $\mathrm{T}$ cells present in the normal lamina propria. Functional impairment or loss of these activated regulatory cells by HIV infection thus could lead to the hyporegenerative villous atrophy seen in patients with detectable HIV-infected cells in the mucosa, as well as to the inadequate crypt hyperplasia seen in patients with secondary infections

\section{References}

1. Barre, S. F., Chermann, J. C., Rey, F., Nugeyre, M. T., Chamaret, S., Gruest, J., Dauguet, C., Axler, B. C., Vezinet, B. F., Rouzioux, C., Rozenbaum, W. and Montagnier, L. (1983). Isolation of a T-lymphotropic retrovirus from a patient at risk for acquired immune deficiency syndrome (AIDS). Science, 220, 868-71

2. Popovic, M., Sarngadharan, M. G., Read, E. and Gallo, R. C. (1984). Detection, isolation, and continuous production of cytopathic retroviruses (HTLV-III) from patients with AIDS and pre-AIDS. Science, 224, 497-500

3. Clavel, F., Guyader, M., Guetard, D., Salle, M., Montagnier, L. and Alizon, M. (1986). Molecular cloning and polymorphism of the human immune deficiency virus type 2. Nature, 324, 691-5 


\section{THE GUT IN HIV INFECTION}

4. Franchini, G., Collalti, E., Arya, S. K., Fenyo, E. M., Biberfeld, G., Zagury, J. F., Kanki, P. J., Wong, S. F. and Gallo, R. C. (1987). Genetic analysis of a new subgroup of human and simian T-lymphotropic retroviruses: HTLV-IV, LAV-2, SBL-6669, and STLV-IIIAGM. Aids Res. Hum. Retroviruses, 3, 11-17

5. Statistics from the World Health Organization and the Centers for Disease Control (1990). AIDS, 4, 1305-10

6. Janoff, E. N. and Smith, P. D. (1988). Perspectives on gastrointestinal infections in AIDS. Gastroenterol. Clin. N. Am., 17, 451-63

7. Smith, P. D. and Janoff, E. N. (1988). Infectious diarrhea in human immunodeficiency virus infection. Gastroenterol. Clin. N. Am., 17, 587-98

8. Riecken, E. O., Zeitz, M. and Ullrich, R. (1990). Non-opportunistic causes of diarrhoea in HIV infection. Bailliere's Clin. Gastroenterol., 4, 385-403

9. Kotler, D. P., Gaetz, H. P., Lange, M., Klein, E. B. and Holt, P. R. (1984). Enteropathy associated with the acquired immunodeficiency syndrome. Ann. Intern. Med., 101, 421-8

10. Ullrich, R., Zeitz, M., Heise, W., L'age, M., Höffken, G. and Riecken, E. O. (1989). Small intestinal structure and function in patients infected with human immunodeficiency virus (HIV): Evidence for HIV-induced enteropathy. Ann. Intern. Med., 111, 15-21

11. MacDonald, T. T. and Spencer, J. (1988). Evidence that activated mucosal T cells play a role in the pathogenesis of enteropathy in human small intestine. J. Exp. Med., 167, 1341-9

12. Riecken, E. O., Stallmach, A., Zeitz, M., Schulzke, J. D., Menge, H. and Gregor, M. (1989). Growth and transformation of the small intestinal mucosa - importance of connective tissue, gut associated lymphoid tissue and gastrointestinal regulatory peptides. Gut, 30, 1630-40

13. Dworkin, B., Wormser, G. P., Rosenthal, W. S., Heier, S. K., Braunstein, M., Weiss, L., Jankowski, R., Levy, D. and Weiselberg, S. (1985). Gastrointestinal manifestations of the acquired immunodeficiency syndrome: a review of 22 cases. Am. J. Gastroenterol., 80, 774-8

14. Friedman, S. L., Wright, T. L. and Altman, D. F. (1985). Gastrointestinal Kaposi's sarcoma in patients with acquired immunodeficiency syndrome. Gastroenterology, 89, 102-8

15. René, E., Marche, C., Regnier, B., Saimot, A. G., Vilde, J. L., Perrone, C., Michon, C., Wolf, M., Chevalier, T., Vallot, T., Brun-Vesinet, F., Pangon, P., Deluol, A. M., Camus, F., Roze, C., Pignon, J. P., Mignon, M. and Bonfils, S. (1989). Intestinal infections in patients with acquired immunodeficiency syndrome. Dig. Dis. Sci., 34, 773-80

16. Smith, P. D., Lane, H. C., Gill, V. G., Manischewitz, J. F., Quinnan, G. V., Fauci, A. S. and Masur, H. (1988). Intestinal infections in patients with the acquired immunodeficiency syndrome (AIDS). Etiology and response to therapy. Ann. Intern. Med., 108, 328-33

17. Colebunders, R., Lusakumuni, K., Nelson, A. M., Gigase, P., Lebughe, I., vanMarck, E., Kapita, B., Francis, H., Salaun, J. J., Quinn, T. C. and Piot, P. (1988). Persistent diarrhoea in Zairian AIDS patients: an endoscopic and histological study. Gut, 29, 1687-91

18. Connolly, G. M., Shanson, D., Hawkins, D. A., Webster, J. N. and Gazzard, B. G. (1989). Non-cryptosporidial diarrhoea in human immunodeficiency virus (HIV) infected patients. Gut, 30, 195-200

19. Heise, W., Mostertz, P., Skörde, J. and L'age, M. (1988). Gastrointestinale Befunde bei der HIV-Infektion. Dtsch. Med. Wochenschr., 113, 1588-93

20. Laughon, B. E., Druckman, D. A., Vernon, A., Quinn, T. C., Polk, B. F., Modlin, J. F., Yolken, R. H. and Bartlett, J. G. (1988). Prevalence of enteric pathogens in homosexual men with and without acquired immunodeficiency syndrome. Gastroenterology, 94, 984-93

21. Gillin, J. S., Shike, M., Alcock, N., Urmacher, C., Krown, S., Kurtz, R. C., Lightdale, C. J. and Winawer, S. J. (1985). Malabsorption and mucosal abnormalities of the small intestine in the acquired immunodeficiency syndrome. Ann. Intern. Med., 102, 619-22

22. Harriman, G. R., Smith, P. D., Horne, M. K., Fox, C. H., Koenig, S., Lack, E. E., Lane, H. C. and Fauci, A. S. (1989). Vitamin $B_{12}$ malabsorption in patients with acquired immunodeficiency syndrome. Arch. Intern. Med., 149, 2039-41

23. Conolly, G. M., Forbes, A. and Gazzard, B. G. (1990). Investigation of seemingly pathogen-negative diarrhoea in patients infected with HIV1. Gut, 31, 886-9

24. Kotler, D. P., Francisco, A., Clayton, F., Scholes, J. V. and Orenstein, J. M. (1990). Small intestinal injury and parasitic disease in AIDS. Ann. Intern. Med., 113, 444-9

25. McDougal, J. S., Kennedy, M. S., Sligh, J. M., Cort, S. P., Mawle, A. and Nicholson, J. K. (1986). Binding of HTLV-III/LAV to T4 $+\mathrm{T}$ cells by a complex of the $110 \mathrm{~K}$ viral protein and the T4 molecule. Science, 231, 382-5 


\section{IMMUNOLOGY OF GASTROINTESTINAL DISEASE}

26. Rosenberg, Z. F. and Fauci, A. S. (1989). The immunopathogenesis of HIV infection. Adv. Immunol., 47, 377-431

27. Ho, D. D., Rota, T. R. and Hirsch, M. S. (1986). Infection of monocyte/macrophages by human T lymphotropic virus type III. J. Clin. Invest., 77, 1712-5

28. Stewart, S. J., Fujimoto, J. and Levy, R. (1986). Human T lymphocytes and monocytes bear the same Leu-3(T4) antigen. J. Immunol., 136, 3773-8

29. Gartner, S., Markovits, P., Markovitz, D. M., Kaplan, M. H., Gallo, R. C. and Popovic, M. (1986). The role of mononuclear phagocytes in HTLV-III/LAV infection. Science, 233, 215-9

30. Crowe, S., Mills, J. and McGrath, M. S. (1987). Quantitative immunocytofluorographic analysis of CD4 surface antigen expression and HIV infection of human peripheral blood monocyte/macrophages. Aids Res. Hum. Retroviruses, 3, 135-45

31. Bolognesi, D. P. (1989). AIDS. Do antibodies enhance the infection of cells by HIV? [news]. Nature, 340, 431-2

32. Takeda, A., Tuazon, C. U. and Ennis, F. A. (1988). Antibody-enhanced infection by HIV-1 via Fc receptor-mediated entry. Science, 242, 580-3

33. Nicholson, J. K., Cross, G. D., Callaway, C. S. and McDougal, J. S. (1986). In vitro infection of human monocytes with human T lymphotropic virus type III/lymphadenopathy-associated virus (HTLV-III/LAV). J. Immunol., 137, 323-9

34. Tenner-Racz, K., Racz, P., Bofill, M., Schulz-Meyer, A., Dietrich, M., Kern, P., Weber, J., Pinching, A. J., Veronese-Dimarzo, F., Popovic, M., Klatzmann, D., Gluckman, J. C. and Janossy, G. (1986). HTLV-III/LAV viral antigens in lymph nodes of homosexual men with persistent generalized lymphadenopathy and AIDS. Am. J. Pathol., 123, 9-15

35. Schriever, F., Freedman, A. S., Freeman, G., Messner, E., Lee, G., Daley, J. and Nadler, L. M. (1989). Isolated human follicular dendritic cells display a unique antigenic phenotype. J. Exp. Med., 169, 2043-58

36. Biberfeld, P., Chayt, K. J., Marselle, L. M., Biberfeld, G., Gallo, R. C. and Harper, M. E. (1986). HTLV-III expression in infected lymph nodes and relevance to pathogenesis of lymphadenopathy. Am. J. Pathol., 125, 436-42

37. Jarry, A., Cortez, A., René, E., Muzeau, F. and Brousse, N. (1990). Infected cells and immune cells in the gastrointestinal tract of AIDS patients. An immunohistochemical study of 127 cases. Histopathology, 16, 133-40

38. Racz, P. (1990). Pathomorphologie des intestinalen Immunsystems. Presented at the 3rd German AIDS-Congress, 17-24 November, Hamburg

39. Nelson, J. A., Wiley, C. A., Reynolds-Kohler, C., Reese, C. E., Margaretten, W. and Levy, J. A. (1988). Human immunodeficiency virus detected in bowel epithelium from patients with gastrointestinal symptoms. Lancet, 1, 259-62

40. Fox, C. H., Kotler, D., Tierney, A., Wilson, C. S. and Fauci, A. S. (1989). Detection of HIV-1 RNA in the lamina propria of patients with AIDS and gastrointestinal disease. $J$. Infect. Dis., 159, 467-71

41. Adachi, A., Koenig, S., Gendelmann, H. E., Daugherty, D., Gattoni, C. S., Fauci, A. S. and Martin, M. (1987). Productive, persistent infection of human colorectal cell lines with human immunodeficiency virus. J. Virol., 61, 209-13

42. Bourinbaiar, A. S. and Phillips, D. M. (1990). HIV transmission across intact epithelia. VIIIth International Congress of Virology

43. Leonard, R., Zagury, D., Desportes, I., Bernard, J., Zagury, J. F. and Gallo, R. C. (1988). Cytopathic effect of human immunodeficiency virus in T4 cells is linked to the last stage of virus infection. Proc. Natl. Acad. Sci. USA, 85, 3570-4

44. Lynn, W. S., Tweedale, A. and Cloyd, M. W. (1988). Human immunodeficiency virus (HIV-1) cytotoxicity: perturbation of the cell membrane and depression of phospholipid synthesis. Virology, 163, 43-51

45. Hoxie, J. A., Alpers, J. D., Rackowski, J. L., Huebner, K., Haggarty, B. S., Cedarbaum, A. J. and Reed, J. C. (1986). Alterations in T4 (CD4) protein and mRNA synthesis in cells infected with HIV. Science, 234, 1123-7

46. Shaw, G. M., Hahn, B. H., Arya, S. K., Groopman, J. E., Gallo, R. C. and Wong, S. F. (1984). Molecular characterization of human T-cell leukemia (lymphotropic) virus type III in the acquired immune deficiency syndrome. Science, 226, 1165-71

47. Lifson, J. D., Feinberg, M. B., Reyes, G. R., Rabin, L., Banapour, B., Chakrabarti, S., Moss, B., Wong, S. F., Steimer, K. S. and Engleman, E. G. (1986). Induction of CD4-dependent 


\section{THE GUT IN HIV INFECTION}

cell fusion by the HTLV-III/LAV envelope glycoprotein. Nature, 323, 725-8

48. Lifson, J. D., Reyes, G. R., McGrath, M. S., Stein, B. S. and Engleman, E. G. (1986). AIDS retrovirus induced cytopathology: giant cell formation and involvement of CD4 antigen. Science, 232, 1123-7

49. Katz, J. D., Nishanian, P., Mitsuyasu, R. and Bonavida, B. (1988). Antibody-dependent cellular cytotoxicity (ADCC)-mediated destruction of human immunodeficiency virus (HIV)-coated CD4 + T lymphocytes by acquired immunodeficiency syndrome (AIDS) effector cells. J. Clin. Immunol., 8, 453-8

50. Lyerly, H. K., Matthews, T. J., Langlois, A. J., Bolognesi, D. P. and Weinhold, K. J. (1987). Human T-cell lymphotropic virus IIIB glycoprotein (gp120) bound to CD4 determinants on normal lymphocytes and expressed by infected cells serves as target for immune attack. Proc. Natl. Acad. Sci. USA, 84, 4601-5

51. Lanzavecchia, A., Roosnek, E., Gregory, T., Berman, P. and Abrignani, S. (1988). T cells can present antigens such as HIV gp120 targeted to their own surface molecules. Nature, $334,530-2$

52. Lane, H. C. and Fauci, A. S. (1985). Immunologic abnormalities in the acquired immunodeficiency syndrome. Annu. Rev. Immunol., 3, 477-500

53. Lane, H. C., Masur, H., Edgar, L. C., Whalen, G., Rook, A. H. and Fauci, A. S. (1983). Abnormalities of B-cell activation and immunoregulation in patients with the acquired immunodeficiency syndrome. $N$. Engl. J. Med., 309, 453-8

54. Lane, H. C., Depper, J. M., Greene, W. C., Whalen, G., Waldmann, T. A. and Fauci, A. S. (1985). Qualitative analysis of immune function in patients with the acquired immunodeficiency syndrome. Evidence for a selective defect in soluble antigen recognition. N. Engl. J. Med., 313, 79-84

55. Shearer, G. M., Bernstein, D. C., Tung, K. S., Via, C. S., Redfield, R., Salahuddin, S. Z. and Gallo, R. C. (1986). A model for the selective loss of major histocompatibility complex self-restricted $\mathrm{T}$ cell immune responses during the development of acquired immune deficiency syndrome (AIDS). J. Immunol., 137, 2514-21

56. Giorgi, J. V., Fahey, J. L., Smith, D. C., Hultin, L. E., Cheng, H. L., Mitsuyasu, R. T. and Detels, R. (1987). Early effects of HIV on CD4 lymphocytes in vivo. J. Immunol., 138, 3725-30

57. Hoy, J. F., Lewis, D. E. and Miller, G. G. (1988). Functional versus phenotypic analysis of $\mathrm{T}$ cells in subjects seropositive for the human immunodeficiency virus: a prospective study of in vitro responses to Cryptococcus neoformans. J. Infect. Dis., 158, 1071-8

58. Murray, H. W., Scavuzzo, D. A., Kelly, C. D., Rubin, B. Y. and Roberts, R. B. (1988). T4+ cell production of interferon gamma and the clinical spectrum of patients at risk for and with acquired immunodeficiency syndrome [see comments]. Arch. Intern. Med., 148, 1613-16

59. Antonen, J. and Krohn, K. (1986). Interleukin 2 production in HTLV-III/LAV infection: evidence of defective antigen-induced, but normal mitogen-induced IL-2 production. Clin. Exp. Immunol., 65, 489-96

60. Schellekens, P. T., Roos, M. T., De, W. F., Lange, J. M. and Miedema, F. (1990). Low T-cell responsiveness to activation via CD3/TCR is a prognostic marker for acquired immunodeficiency syndrome (AIDS) in human immunodeficiency virus-1 (HIV-1)-infected men. J. Clin. Immunol., 10, 121-7

61. Yuille, M. A., Hugunin, M., John, P., Peer, L., Sacks, L. V., Poiesz, B. J., Tomar, R. H. and Silverstone, A. E. (1988). HIV-1 infection abolishes CD4 biosynthesis but not CD4 mRNA. J. Acquir. Immune Defic. Syndr., 1, 131-7

62. Stevenson, M., Zhang, X. H. and Volsky, D. J. (1987). Downregulation of cell surface molecules during noncytopathic infection of $T$ cells with human immunodeficiency virus. J. Virol., 61, 3741-8

63. Prince, H. E., Kleinman, S. H., Maino, V. C. and Jackson, A. L. (1988). In vitro activation of T lymphocytes from human immunodeficiency virus (HIV)-seropositive blood donors. I. Soluble interleukin 2 receptor (IL2R) production parallels cellular IL2R expression and DNA synthesis. J. Clin. Immunol., 8, 114-20

64. Van Noesel, C. J., Gruters, R. A., Terpstra, F. G., Schellekens, P. T., van Lier, R. A. and Miedema, F. (1990). Functional and phenotypic evidence for a selective loss of memory $T$ cells in asymptomatic human immunodeficiency virus-infected men. J. Clin. Invest., 86, 293-9

65. De Paoli, P., Battistin, S., Crovatto, M., Modolo, M. L., Carbone, A., Tirelli, U. and Santini, G. (1988). Immunologic abnormalities related to antigenaemia during HIV-1 infection. 


\section{IMMUNOLOGY OF GASTROINTESTINAL DISEASE}

Clin. Exp. Immunol., 74, 317-20

66. Nair, M. P., Pottathil, R., Heimer, E. P. and Schwartz, S. A. (1988). Immunoregulatory activities of human immunodeficiency virus (HIV) proteins: effect of HIV recombinant and synthetic peptides on immunoglobulin synthesis and proliferative responses by normal lymphocytes. Proc. Natl. Acad. Sci. USA, 85, 6498-502

67. Kornfeld, H., Cruikshank, W. W., Pyle, S. W., Berman, J. S. and Center, D. M. (1988). Lymphocyte activation by HIV-1 envelope glycoprotein. Nature, 335, 445-8

68. Pahwa, S., Pahwa, R., Saxinger, C., Gallo, R. C. and Good, R. A. (1985). Influence of the human T-lymphotropic virus/lymphadenopathy-associated virus on functions of human lymphocytes: evidence for immunosuppressive effects and polyclonal B-cell activation by banded viral preparations. Proc. Natl. Acad. Sci. USA, 82, 8198-202

69. Ho, D. D., Pomerantz, R. J. and Kaplan, J. C. (1987). Pathogenesis of infection with human immunodeficiency virus. N. Engl. J. Med., 317, 278-86

70. Farzadegan, H., Polis, M. A., Wolinsky, S. M., Rinaldo, C. J., Sninsky, J. J., Kwok, S., Griffith, R. L., Kaslow, R. A., Phair, J. P., Polk, B. F., et al. (1988). Loss of human immunodeficiency virus type 1 (HIV-1) antibodies with evidence of viral infection in asymptomatic homosexual men. A report from the Multicenter AIDS Cohort Study. Ann. Intern. Med., 108, 785-90

71. Patarca, R., Freeman, G. J., Schwartz, J., Singh, R. P., Kong, Q. T., Murphy, E., Anderson, Y., Sheng, F. Y. W., Singh, P., Johnson, K. A., Guarnagia, S. M., Durfee, T., Blattner, F. and Cantor, H. (1988). rpt-1, an intracellular protein from helper/inducer $T$ cells that regulates gene expression of interleukin 2 receptor and human immunodeficiency virus type 1 [published erratum appears in Proc. Natl. Acad. Sci. USA, 1988, 85(14), 5224]. Proc. Natl. Acad. Sci. USA, 85, 2733-7

72. Nabel, G. and Baltimore, D. (1987). An inducible transcription factor activates expression of human immunodeficiency virus in T cells. Nature, 326, 711-13

73. Kawakami, K., Scheidereit, C. and Roeder, R. G. (1988). Identification and purification of a human immunoglobulin-enhancer-binding protein (NF-kappa B) that activates transcription from a human immunodeficiency virus type 1 promoter in vitro. Proc. Natl. Acad. Sci. $U S A, 85,4700-4$

74. Gendelman, H. E., Phelps, W., Feigenhaum, L., Ostrove, J. M., Adachi, A., Howley, P. M., Khoury, G., Ginsberg, H. S. and Martin, M. A. (1986). Transactivation of the human immunodeficiency virus long terminal repeat sequence by DNA viruses. Proc. Natl. Acad. Sci. USA, 83, 9759-63

75. Davis, M. G., Kenney, S. C., Kamine, J., Pagano, J. S. and Huang, E. S. (1987). Immediate-early gene region of human cytomegalovirus trans-activates the promoter of human immunodeficiency virus. Proc. Natl. Acad. Sci. USA, 84, 8642-6

76. Kenney, S., Kamine, J., Markovitz, D., Fenrick, R. and Pagano, J. (1988). An Epstein-Barr virus immediate-early gene product trans-activates gene expression from the human immunodeficiency virus long terminal repeat. Proc. Natl. Acad. Sci. USA, 85, 1652-6

77. Rando, R. F., Pellett, P. E., Luciw, P. A., Bohan, C. A. and Srinivasan, A. (1987). Transactivation of human immunodeficiency virus by herpesviruses. Oncogene, 1, 13-8

78. Folks, T. M., Justement, J., Kinter, A., Dinarello, C. A. and Fauci, A. S. (1987). Cytokine-induced expression of HIV-1 in a chronically infected promonocyte cell line. Science, 238, 800-2

79. Rosenberg, Z. F. and Fauci, A. S. (1990). Immunopathogenic mechanisms of HIV infection: cytokine induction of HIV expression. Immunol. Today, 11, 176-80

80. Clouse, K. A., Powell, D., Washington, I., Poli, G., Strebel, K., Farrar, W., Barstad, P., Kovacs, J., Fauci, A. S. and Folks, T. M. (1989). Monokine regulation of human immunodeficiency virus- 1 expression in a chronically infected human $\mathrm{T}$ cell clone. $J$. Immunol., 142, 431-8

81. Duh, E. J., Maury, W. J., Folks, T. M., Fauci, A. S. and Rabson, A. B. (1989). Tumor necrosis factor alpha activates human immunodeficiency virus type 1 through induction of nuclear factor binding to the NF-kappa B sites in the long terminal repeat. Proc. Natl. Sci. USA, 86, 5974-8

82. Folks, T. M., Clouse, K. A., Justement, J., Rabson, A., Duh, E., Kehrl, J. H. and Fauci, A. S. (1989). Tumor necrosis factor alpha induces expression of human immunodeficiency virus in a chronically infected T-cell clone. Proc. Natl. Acad. Sci. USA, 86, 2365-8 


\section{THE GUT IN HIV INFECTION}

83. Selby, W. S., Jannossy, G., Bofill, M. and Jewell, D. P. (1984). Intestinal lymphocyte subpopulations in inflammatory bowel disease: an analysis by immunohistological and cell isolation techniques. Gut, 25, 32-40

84. James, S. P., Fiocchi, C., Graeff, A. S. and Strober, W. (1986). Phenotypic analysis of lamina propria lymphocytes: Predominance of helper-inducer and cytolytic T-cell phenotypes and deficiency of suppressor-inducer phenotypes in Crohn's disease and control patients. Gastroenterology, 91, 1483-9

85. James, S. P., Graeff, A. S. and Zeitz, M. (1987). Predominance of helper-inducer T cells in mesenteric lymph node and intestinal lamina propria lymphocytes of normal non-human primates. Cell. Immunol., 107, 372-83

86. Schieferdecker, H. L., Ullrich, R., Weiss-Breckwoldt, A. N., Schwarting, R., Stein, H., Riecken, E. O. and Zeitz, M. (1990). The HML-1 antigen of intestinal lymphocytes is an activation antigen. J. Immunol., 144, 2541-9

87. Zeitz, M., Schieferdecker, H. L., James, S. P. and Riecken, E. O. (1990). Special functional features of T-lymphocyte subpopulations in the effector compartment of the intestinal mucosa and their relation to mucosal transformation. Digestion, 46 (Suppl. 2), 280-9

88. Sanders, M. E., Makgoba, M. W., Sharrow, S. O., Stephany, D., Springer, T. A., Young, H. A. and Shaw, S. (1988). Human memory T lymphocytes express increased levels of three cell adhesion molecules (LFA-3, CD2 and LFA-1) and three other molecules (UCHL1, CDw29 and Pgp-1) and have enhanced IFN-production. J. Immunol., 140, 1401-7

89. Sanders, M. E., Makgoba, M. and Shaw, S. (1988). Human naive and memory T cells: reinterpretation of helper-inducer and suppressor-inducer subsets. Immunol. Today, 9, 195-9

90. Cerf-Bensussan, N., Jarry, A., Brousse, N., Liskowska-Grospierre, B., Guy-Grand, D. and Griscelli, C. (1987). A monoclonal antibody (HML-1) defining a novel membrane molecule present on human intestinal lymphocytes. Eur. J. Immunol., 17, 1279-85

91. Zeitz, M., Quinn, T. C., Graeff, A. S. and James, S. P. (1988). Mucosal T cells provide helper function but do not proliferate when stimulated by specific antigen in lymphogranuloma venereum proctitis in nonhuman primates. Gastroenterology, 94, 353-66

92. Zeitz, M., Greene, W. C., Peffer, N. J. and James, S. P. (1988). Lymphocytes isolated from the intestinal lamina propria of normal nonhuman primates have increased expression of genes associated with T cell activation. Gastroenterology, 94, 647-55

93. Zeitz, M., James, S. P., Ullrich, R. and Riecken, E. O. (1989). Characteristics of intestinal T lymphocytes as potential target cells of HIV. In Classen, M. and Dancygier, H. (eds), AIDS in Gastroenterology and Hepatology. Gräfelfing: Demeter Verlag, pp. 14-17

94. Rodgers, V,. D., Fassett, R. and Kagnoff, M. F. (1986). Abnormalities in intestinal mucosal $\mathrm{T}$ cells in homosexual populations including those with the lymphadenopathy syndrome and acquired immunodeficiency syndrome. Gastroenterology, 90, 552-8

95. Ellakany, S., Whiteside, T. L., Schade, R. R. and vanThiel, D. H. (1987). Analysis of intestinal lymphocyte subpopulations in patients with acquired immunodeficiency syndrome (AIDS) and AIDS-related complex. Am. J. Clin. Pathol., 87, 356-64

96. Budhraja, M., Levendoglu, H., Kocka, F., Mangkornkanok, M. and Sherer, R. (1987). Duodenal mucosal $\mathrm{T}$ cell subpopulation and bacterial cultures in acquired immune deficiency syndrome. Am. J. Gastroenterol., 82, 427-31

97. Zeitz, M., Ullrich, R. and Riecken, E. O. (1990). The role of the gut-associated lymphoid tissue in the pathogenesis of the acquired immunodeficiency syndrome (HIV-infection). In MacDonald, T. T., Challacombe, S. J., Bland, P. W., Stokes, C. R., Heatley, R. V. and Mowat, A. M. (eds), Advances in Mucosal Immunology. Proceedings of the Fifth International Congress of Mucosal Immunology. Dordrecht: Kluwer, pp. 655-9

98. Ullrich, R., Zeitz, M., Heise, W., L'age, M., Ziegler, K., Bergs, C. and Riecken, E. O. (1990). Mucosal atrophy is associated with loss of activated $\mathrm{T}$ cells in the duodenal mucosa of human immunodeficiency virus (HIV)-infected patients. Digestion, 46 (Suppl. 2), 302-7

99. Weber, J. R., Jr. and Dobbins, W. O. (1986). The intestinal and rectal epithelial lymphocyte in AIDS. Am. J. Surg. Pathol., 10, 627-39

100. Batman, P. A., Miller, A. R. O., Forster, S. M., Harris, J. R., Pinching, A. J. and Griffin, G. E. (1989). Jejunal enteropathy associated with human immunodeficiency virus infection: quantitative histology. J. Clin. Pathol., 42, 275-81

101. Cummins, A. G., LaBrooy, J. T., Stanley, D. P., Rowland, R. and Shearman, D. J. C. (1990). A quantitative histological study of enteropathy associated with HIV infection. In 


\section{IMMUNOLOGY OF GASTROINTESTINAL DISEASE}

MacDonald, T. T., Challacombe, S. J., Bland, P. W., Stokes, C. R., Heatley, R. V. and Mowat, A. M. (eds), Advances in Mucosal Immunology. Proceedings of the Fifth International Congress of Mucosal Immunology. Dordrecht: Kluwer, pp. 669-70

102. Kotler, D. P., Scholes, J. V. and Tierney, A. R. (1987). Intestinal plasma cell alterations in the acquired immunodeficiency syndrome. Dig. Dis. Sci., 32, 129-38

103. Jackson, S. (1990). Secretory and serum IgA are inversely altered in AIDS patients. In MacDonald, T. T., Challacombe, S. J., Bland, P. W., Stokes, C. R., Heatley, R. V. and Mowat, A. M. (eds), Advances in Mucosal Immunology. Proceedings of the Fifth International Congress of Mucosal Immunology. Dordrecht: Kluwer, pp. 665-8

104. Griffiths, C. E., Barrison, I. G., Leonard, J. N., Caun, K., Valdimarsson, H. and Fry, L. (1988). Preferential activation of CD4 T lymphocytes in the lamina propria of gluten-sensitive enteropathy. Clin. Exp. Immunol., 72, 280-3

105. Cummins, A. G., LaBrooy, J. T., Stanley, D. et al. (1990). Quantitative histological study of enteropathy associated with HIV infection. Gut, 31, 317-21

106. Quinn, T. C. (1989). Protozoon infections in the gastrointestinal tract of homosexual men and patients with the acquired immunodeficiency syndrome. In Classen, $M$. and Dancygier, H. (eds), AIDS in Gastroenterology and Hepatology. Gräfelfing: Demeter Verlag, pp. 36-8 